${ }^{2}$ The University of Georgia

\title{
Issues of Country of Origin, Market Incentives, and Recycling in Opinions of Passive Solar Collector Owners
}

\begin{abstract}
Thermal solar panel installation has been growing in Poland in response to the EU policies and available subsidies. This paper investigates the attitudes of residents of four counties in Mazowieckie Voividship in Poland about the origin of solar panels. Results show that rural residents did not attach importance to awarding preferences to domestic solar panel producers or to foreign producers in exchange of trade benefits. The recycling of used solar panels concerned a relatively small portion of respondents and seems to justify the passage of regulations obligating the solar panel industry to recycle the used panels.
\end{abstract}

Key words: Renewable energy, survey, rural resident, recycling, Poland,

JEL Classification: Q56, Q20, Q42

\section{Introduction}

Solar thermal plants help save 40.3 million tons of oil and reduce $\mathrm{CO}_{2}$ emissions by 130 million tons per year (Weiss et al., 2017, 2018). At the end of 2015, the total installed capacity of 435.9 GWth corresponded to 622.7 million square meters of collector area in operation worldwide. Based on Solar Head Worldwide (Weiss et al., 2017), China and Europe are the dominant solar panel markets and account for $82.3 \%$ of the total installed capacity (309.5 GWth in China and 49.2 GW th in Europe).

The passive solar panel market in Poland offers various models made by various domestic and foreign manufacturers. Some distributors suggest that the domestically manufactured panels are better engineered and the installation is better suited to the relatively harsh Polish winters than the imported panels. Distributors also stress the readily available conservation and repair service for domestically produced passive solar panels, which is not always the case with the imported equipment. Solar energy generation includes grid-connected and off-grid installations, although in Poland the first wave of installations was limited to solar thermal panels used to heat water and was supported by generous subsidies from the European Union (EU).

With the growing surface of passive solar panels installed by Polish households, the emerging issue, as illustrated by developments in other countries where solar energy

\footnotetext{
$1 \mathrm{PhD}$, Faculty of Production Engineering WULS - SGGW, 164 Nowoursynowska St., 02-787 Warsaw, e-mail: anna_klepacka@sggw.pl; https://orcid.org/0000-0002-2828-5429

${ }^{2}$ Professor, Department of Agricultural and Applied Economics, The University of Georgia, 1109 Experimental St., 212 Stuckey Building, Griffin, Georgia 30223-1797, USA, e-mail: wojciech@uga.edu; https://orcid.org/0000-0003-1947-2182

3 BA, Faculty of Production Engineering WULS - SGGW, 164 Nowoursynowska St., 02-787 Warsaw, e-mail: kaatarzyna.wojcikk@gmail.com
} 
utilization has longer history, is the recycling of used panels. The panels are bulky and require special handling by those who attempt their disposal. Many counties organize the collection of household equipment, used furniture, electronics, etc. on a periodic basis, but not more that 2-4 times a year. The specialized solar panel recycling companies have yet to emerge. In countries with a longer history of solar thermal panel installation, the absence of firms willing to undertake panel recycling was initially associated with the inadequate volume of used panels (Xu et al., 2018). In EU, the recycling of solar panels falls under the directive regarding waste electrical and electronic equipment issued in 2012 (Official Journal of the European Union, 2012). Under the directive, solar panels must be collected and recycled.

This paper reviews the opinions of solar thermal panel users with regard to the country of origin, market incentives and inducements for domestic and foreign solar panel manufacturers, and panel recycling using survey data from residents of a four-county area in Mazowieckie Voivodship in Poland. The available solar panel models vary, but the projects involving solar panel subsidies often limit the choice of models preventing the individual investor from choosing a particular panel. At the same time, the declared benefits of renewable energy utilization list job creation as a major benefit (Tsoutos et al., 2005). Given the relatively greater unemployment in Poland's rural than urban areas, the preference for a domestically manufactured panel could be an important solar panel selection criterion. Concerning recycling, the technology for recycling solar thermal panels has been developed (Klugman-Radziemska, Ostrowski, 2009) and allows the recovery of silica, several rare metals, glass, aluminum, plastics, and other components (Fthenakis, 2000). However, there is a lack of studies about opinions of the thermal solar panel users regarding the broad issue of preferential treatment of domestic industry and the long-term consequences of disposing of used panels.

\section{Solar energy: production, equipment sales, and recycling}

Within Europe, Poland's solar collector market has been growing although it remains relatively small. IEO reported that 70 domestic panel manufacturers and foreign companies offered equipment and full solar installations in Poland in 2010 (Więcka, 2011). A few years later, in 2014, 74 firms manufactured and distributed solar panels; one half of them represented foreign firms (Wengierek, 2014). Nearly 50\% of solar panels made in Poland was sold abroad, including Germany, Spain, Portugal, Great Britain, Sweden, Finland, Czechia, and Slovakia. In 2018, the list of solar panel manufacturers contains names of 32 domestic companies and confirms that their number remains relatively stable (http://gieldaoze.pl/news/show/43/producenci-kolektorow-slonecznych-w-polsce).

A much different situation has developed in the sector of solar panel distribution and installation services. According to Business Navigation (https://www.baza-firm.com.pl) 1066 firms engaged in solar panel collector sales were registered in all voivodships on April 26, 2018. Their number was 9\% higher than in 2014. The largest number of registered solar panel dealers and service providers was in Śląskie, Mazowieckie, and Małopolskie Voivodships (178, 136, and 129, respectively), while in Warmińsko-mazurskie, Opolskie, and Podlaskie the number of registered firms was lowest (22, 26, and 29, respectively). The spatial differences in the number of registered firms and the number of installed solar energy systems is determined, among other reasons, by the solar radiation intensity or the EU subsidies (Klepacka, 2018) as well as the spatial distribution of firms (Park NaukowoTechnologiczny Euro-Centrum, 2014). 
The total area of installed solar panels amounted to $51 \mathrm{mln} \mathrm{m}^{2}$ in Europe in 2016 (Eurobserv'er, 2017). The area installed in 2016 alone was $2.6 \mathrm{mln} \mathrm{m}^{2}$, or $4.6 \%$ less than a year earlier. Germany has the largest area of installed solar panels followed by Denmark, Greece, Spain, Italy, France and, finally, Poland. The declining financial support program is blamed for the shrinking number of installations in residential housing.

The use of passive solar panel utilization (https://sjp.pl/utylizacja) and recycling (Ustawa, 2001; Official Journal of the European Union, 2012) is less widespread than PV panels because of the applied technology. Firms distributing and installing the PV panels expand their services and participate in panel recycling. Many voluntarily adopt ISO 14000 and ISO 26000 standards encompassing environmental protection norms and business social responsibility. Within the EU, Directive No 2002/96/EU governs the disposal of used electric and electronic equipment (Official Journal of the European Union 2012). Solar panel manufacturers are obligated to collect and recycle sold panels (http://bluesol.pl/zuzytemoduly-fotwoltaiczne-recykling-pv-na-swiecie).

Hewalex, a Polish solar panel manufacturer, provides an example of considering the recycling of waste generated in production from legal, economic, manufacturing, and ecological perspectives (Wengierek, 2014). The various perspectives include, among others, cataloging the waste, recovery of recyclable materials, establishment of firms collecting and recycling used solar panels, and reduction of the use of toxic substances. The toxic substances include heavy metals (tin, cadmium, and lead) and if not recovered cause the waste to be reclassified as "hazardous" which can only be discarded in to designated landfills. Xu et al. (2018) provide a summary of all recyclable components of solar energy panels illustrating the opportunities as well as potential negative environmental effects if recycling does not take place.

\section{Materials and methods}

Solar panel recycling is subject to waste management or environmental protection regulations, but is seldom a topic of research on the actual outcomes because of the systemic lack of data. To address the issue of solar panel recycling, especially as the amount of used panels is increasing globally, requires the collection of data. A data collection effort is commonly restricted in scope because of the involved costs and spatial limitations. Similarly, the knowledge of public opinion about the broader issues of incentives and privileges for panel manufacturers is virtually non-existent. A researcher interested in such topics has to undertake a project and fill the existing data gap. The major limitation is identification of the target population, which in this case is the group of solar panel owners. Solar panel owners tend to reside in areas where the EU-funded renewable energy project was implemented, and the concentration of owners facilitates the organization of a survey.

The selection of counties was based on their participation in the EU-funded project "Słoneczne gminy Wschodniego Mazowsza - energia solarna energia przyszłości" (The sunny counties of eastern Masovia - solar energy, the energy of the future). The data were collected through a survey using a questionnaire containing 20 questions specific to renewable energy issues and a set of questions probing the respondent for socio-economic and demographic information. The survey was implemented in the spring of 2017. A total of 94 completed questionnaires were collected from residents of four counties, including 26 from Przesmyki County, 16 from Paprotnia, 24 from Korczew, and 28 from Repki County. 
The questions probing for the respondent's opinions about the importance of panel origins, awarding preferences, and the importance of panel recycling offered five response options. A respondent was presented a Likert-type, five-step scale ranging from $1=$ not important at all to $5=$ very important; the middle option implied a neutral opinion (neither important nor unimportant). The results of the survey are presented in the descriptive form supported by the tabulated summary of responses. The differences in opinions about the specific issues are tested using SAS software. The test examined the significant differences between the selected personal characteristics of respondents and the presented statements. The results infrequently confirm the existence of statistically significant differences suggesting a need for future studies to expand the scope of the current investigation.

\section{Results and discussion}

The EU support for country-members ran from 2007-2013 (Rakowska, 2016). The funds under the cohesion program were allocated through the European Fund for Regional Development among the 16 voivodships in Poland. Mazowieckie Voivodship implemented the "Operational Program of Mazowieckie Voivodship 2003-1017", Priority IV Environment prevents threats and energy, Task 4.3 "Air quality protection-Renewable energy source and co-generation". Within the program counties of Repki, Korczew, Paprotnia, and Przesmyki developed the project "Sunny counties of Eastern Masovia solar energy, energy of the future" (Stawicki, 2009). The rural households participating in the project received subsidies for the purchase and installation of solar collectors of up to $70 \%$ of the total project value of 9.9 million PLN (Sendrowicz, 2014). The project planned for the installation of passive solar panels in 100 villages in the four counties, specifically in Repki County - 583 households (Siedlce district), Przesmyki County - 348 households (Sokołow district), Korczew County - 239 households (Siedlce district), and Paprotnia County - 226 household (Siedlce district) ${ }^{4}$.

The participants in the survey originated from all counties: $28 \%$ were the residents of Przesmyki County, 17\% from Paprotnia County, 26\% from Korczew County, and 29\% from Repki County. Among the survey participants, 57\% were women and 43\% were men. The number of household members varied and in $68 \%$ there were four or more members, three members were reported in $17 \%$ of households, two in $13 \%$, and $2 \%$ were singleperson households. The number of children in households also varied. Two children under 18 years old or younger were in $24 \%$ of households, one child was in $15 \%$ of households, $9 \%$ of households had three children, while $3 \%$ had four or more children. The remaining $49 \%$ of households did not have children 18 years old or younger.

The respondents selected an answer from the five options ranging from "not important at all" to "very important". Because the share of responses in the two extreme response categories were few, Table 1 presents only three columns where the bottom tow and top two response options were combined to account for lack of attached importance and importance, respectively.

\footnotetext{
4 "Sunny counties of Eastern Masovia - solar energy, energy of the future" Przesmyki County.
} 


\section{Country of origin and preferred market access}

This paper focuses on two issues related to solar panel purchase and use. One issue was the respondent opinion about the country of origin of the installed solar panels, giving preference to domestic panel manufacturers even it meant paying higher prices, giving preference to foreign solar panel manufacturers in exchange of importing Polish products, and leaving the solar panel market to a free interaction of market forces.

In response to the question whether the country-of-origin mattered, $39 \%$ of respondents choose the "neither important nor unimportant" option on a five-step scale (Table 1). Only $15 \%$ of respondents selected options "important" or "very important". The largest group of respondents did not feel that was an important issue. The result of the statistical differences accounting for the effects of personal characteristics on the importance of origin shows that respondents from household with children were less likely to view the origin of solar panels as not important $(\mathrm{p}=0.0989)$. Perhaps, such results indirectly captures concerns about the desire to generate jobs by favoring domestic producers.

There was little support for the statement about favoring domestic solar panel manufacturers: $42 \%$ of respondents indicated that it was "neither important nor unimportant". Only $21 \%$ felt that favorably treating the domestic panel producers was important. The balance, $37 \%$, did not think the issue was important. It is worth mentioning that college educated as compared to respondents with less education appear to be more likely to favor domestic producers although the results is marginally insignificant $(p=0.1070)$ and the issue needs future investigation.

Table 1. Summary of responses regarding the five statements about the passive solar panel origin, trade arrangements, and the free interaction of market forces (in \%)

\begin{tabular}{l|ccc}
\hline \multicolumn{1}{c|}{ Statement } & Not important & $\begin{array}{c}\text { Neither important nor } \\
\text { unimportant }\end{array}$ & Important \\
\hline Origin not important & 42.7 & 41.6 & 15.7 \\
Domestic manufacturer favored & 31.8 & 45.4 & 22.7 \\
Domestic higher price & 38.4 & 47.7 & 13.9 \\
Access by foreign producers in exchnage & 40.5 & 52.4 & 7.1 \\
of higher Polish exports & 31.3 & 48.2 & 20.5 \\
Free market & & & \\
\hline
\end{tabular}

Note: "Not important" accounts for responses indicating any of the two levels of unimportance, while "Important" groups responses indicating any of the two levels of importance.

Source: own survey data.

However, the distribution of responses was somewhat different in the case of a statement suggesting favoring domestic solar panel manufacturers even if that meant higher prices to buyers. A large share, $44 \%$, of respondents viewed that issue as "neither important nor unimportant" (Table 1). Only $13 \%$ of the surveyed residents indicated that the issue was "important" or "very important" to them. Although it appears that the respondents adopted attitudes consistent with favoring a free market philosophy despite the relatively high rural unemployment at the time of the survey implementation, the results of the statistical test show that college-educated respondents supported higher prices for domestic panel producers $(\mathrm{p}=0.0967)$ as compared to those with less than college education. 
The respondents also did not appreciate the potential trade benefits from specific arrangements facilitating foreign access to the Polish solar panel market. When asked if the foreign panel manufacturers should be favored in supplying the panels in exchange for increasing imports from Poland, $47 \%$ of respondents thought this was "neither important nor unimportant" (Table 1). A mere $6 \%$ indicated that was an important consideration. The test results show, however, that college educated respondents favorably viewed the possibility of granting access if it meant higher exports from Poland to the country of the foreign solar panel manufacturer $(\mathrm{p}=0.0392)$.

In contrast, $42 \%$ of respondents felt that leaving the solar panel market to the free market force interaction was "neither important nor unimportant", while 18\% selected the option "important" or "very important". Additionally, the test on statistically significant differences indicates that respondents who were farmers in particular favored the free interaction of market forces on the solar panel market as compared to non-farmers $(\mathrm{p}=0.0410)$.

Summing the respondent selections of the level of importance with regard to the five listed issues, the dominating attitude is that of indifference or lack of any strong held view about any of the issues. The most often chosen option was "neither important nor unimportant" but, interestingly, an increasingly larger share of respondents choose a neutral stand on the presented issue, while fewer and fewer respondents attached importance to the issue of preferential treatment of domestic manufacturers and enabling market access in exchange of trade benefits. The plausible explanation is the $70 \%$ subsidy received from the EU funds by each of the participants and owners of a solar energy installation. Such a generous benefit tempered the relative importance of the presented issues regarding favorable access for domestic or foreign panel producers.

\section{Recycling of used solar panels}

In this study an issue presented to respondents also included the recycling or utilization of used solar panels. Each respondent was presented with the following statement about solar panel recycling: "I do not think about what will happen to the used solar panels"; "the installation of solar panels lowered our energy bill"; "I am not interested in what will happen to the used solar panels".

One half of respondents did not think about what would happen to the used panels, but nearly a third, $31 \%$, admitted that they did think about the issue. The attitudes reflected in the expressed opinions were somewhat more disturbing in response to the question of whether a respondent thought about what would happen to the used solar panels. Three in five, $60 \%$, did not think about that issue, while only $18 \%$ indicated that they did. It appears that the immediate benefits from investing in a solar panel set dominated the interest of the respondents because 56\% indicated that their energy bill was lower as a result of having solar panels. Overall, although some surveyed rural residents appear to be forward-thinking and consider the recycling of the panels, it I sup to regulators to enforce the future handling of used panels in an environmentally safe way.

\section{Concluding remarks}

This study addressed two important issues that tend to be ignored in the process of promoting solar energy use, namely, the potential broad economic benefits stemming from solar panel manufacturing and the unavoidable future issue of panel recycling. Panel 
recycling has been addressed by regulations obligating solar panel distributors to accept used panels from homeowners. It is likely that used solar panels can be collected by local waste collection firms on days designated as "bulky household item collection" taking place once or twice a year in various communities. The problem experienced in other countries with an inadequate volume of used solar panels to justify the operation of a specialized recycling facility will not prevent homeowners from properly discarding unwanted panels. Local or regional waste management systems will have to undertake efforts to process the panels or ship them to a recycling site. In the current study, only a minority of respondents revealed concerns about the future handling of used panels, suggesting that the passage of regulations mandating panel recycling is justified.

With regard to the country of origin as well as market incentives and inducements for domestic and foreign solar panel manufacturers, respondents showed little inclination towards distorting market forces by granting any preferential treatment to domestic panel producers or foreign producers in exchange for increased trade. Such attitudes imply that the anticipated job creation associated with solar panel manufacturing will only occur if the regional or Polish panel producer is cost-competitive. Otherwise, the job-creation benefits another country, and possibly a country outside the EU, which promotes and subsidizes household solar panel investment. Solar thermal panels offered on the Polish market originate from either domestic plants or China, although some distributors claim that the domestic panels are of better quality. Such statements result possibly from the higher prices of domestic panels. However, not without importance is the ability to service the installed panels, granting the advantage to domestic manufacturers.

A future study can expand the sample size and the geographic scope to establish if the attitudes displayed by the respondents from the current study reflect nation-wide attitudes. As the subsidy programs expand and include not only rural but also urban residents, the views held with regard to the origin of panels may change. More importantly, the utilization of solar energy expands with the support program for household installation of PV (photovoltaic) panels further altering opinions about preferential treatment and trade. A comparison of attitudes between urban and rural residents will offer opportunities for a new, broader study. Moreover, since the rate of unemployment has decreased since the solar panel support program was implemented in the area studied in the current paper, the effect of increasing job opportunities on views of preferential treatment and trade may justify a future empirical investigation.

\section{Literature}

Baza Firm Business Navigator (Business Navigator database of companies). Available 28 April 2018 from:https://www.baza-firm.com.pl. Accessed on April 28, 2018.

Bluesol. Zużyte moduły fotowoltaiczne. Recykling PV na świecie (Used photovoltaic modules. PV recycling in the world). Available 28 April 2018 from: http://bluesol.pl/zuzyte-moduly-fotwoltaiczne-recykling-pv-naswiecie.

Eurobserv'er. (2017). Solar thermal and concentrated solar power barometers 2017. Juin. Available 28 April 2018 from: https://www.eurobserv-er.org/solar-thermal-and-concentrated-solar-power-barometer-2017-3/.

Fthenakis, V. M. (2000) End-of-life management and recycling of PV modules. Energy Policy. 28, 1051-1058.

Gielda OZE. Producenci kolektorów słonecznych w Polsce (Producers of solar collectors in Poland). Available 28 April 2018 from:http://gieldaoze.pl/news/show/43/producenci-kolektorow-slonecznych-w-polsce.

Klepacka, A.M. (2018). Różnice w koncentracji inwestycji w energię słoneczną z użyciem paneli fotowoltaicznych oraz kolektorów słonecznych w gminach województwa lubelskiego i mazowieckiego 
(Differences in the concentration of solar energy investments using photovoltaic panel and solar collectors in Lubelskie and Mazowieckie Voivodships' municipalities). Roczniki Naukowe Stowarzyszenia Ekonomistów Rolnictwa i Agrobiznesu. 20(1), 73-80.

Klugman-Radziemska, E., Ostrowski, P. (2010). Chemical treatment of crystalline silicon crystal panels as a method of recovery pure silicon from photovoltaic modules. Renewable Energy 35:1751-1759. doi: $10.1016 /$ j.renene.2009.11.031.

Official Journal of the European Union (2012). Directive 2012/19/EU on waste electrical and electronic equipment (WEEE). Available 28 April 2018 from: https://eurlex.europa.eu/LexUriServ/LexUriServ.do?uri=OJ:L:2012:197:0038:0071:EN:PDF.

Park Naukowo-Technologiczny Euro-Centrum. (2014). Rynek kolektorów słonecznych w Polsce i województwie śląskim. Katowice. Available 28 April 2018 from: http://pnt.euro-centrum.com.pl/files/post/830/Rynekkolektorow-slonecznych-w-Polsce-i-wojewodztwie-slaskim.pdf. Accessed on April 28, 2018.

Rakowska, J. (2016). Samorządy gmin jako beneficjenci polityki spójności UE w latach 2007-2013 (2015) (Municipal self-governments as beneficiaries of the European Union's cohesion policy in 2007-2013 (2015)). Wydawnictwo SGGW. Warszawa.

Sendrowicz, B. (2017). Dotacje - rozwijają czy zabijają OZE? Available 28 April 2018 from: http://wyborcza.pl/7,155287,22273708, dotacje-rozwijaja-czy-zabijaja oze.html? disableRedirects=true.

Słownik Języka Polskiego. Downloaded from https://sjp.pl/utylizacja Accessed on April 28, 2018.

Stawicki, M. (2009). Fundusze europejskie w gminach. Rozwój lokalny -wykorzystanie środków UE (European funds in municipalities. Local development - using EU funds). Available 28 April 2018 from:https://depot.ceon.pl/bitstream/.../Fundusze\%20europejskie $\% 20 \mathrm{w} \% 20$ gminach.pdf.

Tsoutsos, T., Frantzeskaki, N., Gekas, V. (2005). Environmental Impacts from the Solar Energy Technologies. Energy Policy, 33, 289-296. doi: 10.1016/S0301-4215(03)00241-6.

Ustawa Z dnia 27 kwietnia 2001 r. o odpadach. Available 28 April 2018 from: http://prawo.sejm.gov.pl/isap.nsf/DocDetails.xsp?id=WDU20010620628.

Weiss, W., Spörk-Dür, M. (2018). Solar Heat Worldwide. Global Market Development and Trends in 2017. Detailed Market Figures 2016. 2018 Edition. AEE - Institute for Sustainable Technologies. IEA Solar Heating \& Cooling Programme, May, 1-89.

Weiss, W., Spörk-Dür, M., Mauthner, F. (2017). Solar Heat Worldwide. Global Market Development and Trends in 2016. Detailed Market Figures 2015. 2017 Edition. AEE - Institute for Sustainable Technologies. IEA Solar Heating \& Cooling Programme, May, 1-83.

Więcka, A. (2011). Niezła pozycja w Europie. Polski rynek kolektorów słonecznych- kierunki rozwoju, producenci, ceny i ... gwarancje (Good position in Europe. Polish market of solar collectors - direction of development, producers, prices and ... guarantees). Instal Reporter. Maj (9), 10-12.

Wengierek, M. (2014). Odzysk i recycling jako metody zagospodarowania odpadów w regionie (Recovery and recycling as a methods of waste management in the region). Zeszyty Naukowe Politechniki Ślaskiej, Seria Organizacja i Zarzadzanie. (70), 477-490.

Xu, Y., Li, J., Tan, Q., Peters, A. L., Yang, C. (2018). Global status of recycling waste solar panels: A review. Waste Management 75:450-458. doi: 10.1016/j.wasman.2018.01.036

\section{For citation:}

Klepacka A.M., Florkowski W.J., Wójcik K. (2018). Issues of Country of Origin, Market Incentives, and Recycling in Opinions of Passive Solar Collector Owners. Problems of World Agriculture, 18(3), 165-172; DOI: 10.22630/PRS.2018.18.3.75 